\title{
Europe reshuffles its scientific committees following BSE crisis
}

[PARIS] The European Commission has, as anticipated, announced a radical reform of its system of scientific advisory committees, removing them from commission departments whose interests could conflict with considerations of public health and consumer protection.

Jacques Santer, the president of the commission, was scheduled to outline the reforms in detail this week before the European Parliament. The measures are partly a response to criticisms by the press and parliament of the commission's handling of bovine spongiform encephalopathy (BSE).

The plenary session of the parliament was itself scheduled to consider the final report of its committee of inquiry into BSE. The parliament is expected to reject a proposal by a small number of its members to pass a motion of censure of the commission.

Under the planned reforms, the commission's scientific committees will be regrouped within a new 'department for scientific advice on health', located within the directorate for consumer policy (DG24), which itself will be renamed "consumer policy and protection of consumer health". The directorate will also be given responsibility for the commission's phytosanitary, veterinary and food inspection services, which were previously attached to the agriculture directorate.

The consumer directorate, which is overseen by commissioner Emma Bonino, will also be equipped with a new unit for the evaluation of public health risks.

Completing these arrangements will be a high-level group made up of commissioners involved in human food safety, to be chaired by Santer himself.

The shake-up of the system of scientific advisory committees is designed to promote greater clarity and openness. The various scientific committees are at present attached to different directorates and operate in a haphazard fashion, with few clear rules governing such matters as how members and chairs of advisory committees are appointed. Also, it has often been almost impossible to find out who sits on committees, let alone obtain the minutes of their meetings.

To remedy this, all advisory committees will be brought under a steering committee which will be responsible for fixing standardized rules as to how committees should be established and operate. The steering committee will itself be built around the multidisciplinary scientific committee set up by the commission last July (see Nature 381, 724; 1996).

"This will be a totally different approach to scientific advice from what we have had in the past," says one commission official. "Now there will be a supercommittee watching the work of the others." Issues surrounding genetically modified organisms, for example, would now first be discussed by the steering committee. It would then decide on how work should be distributed among the various committees and what subgroups, if any, need to be specially created.

The commission and the steering committee will meet tomorrow (21 February) to work out details of how committees should operate. Under preliminary proposals, details of committee members and the minutes of their meetings would be made publicly available, possibly on the Internet.

Declan Butler

\section{Chemists urge US to ratify weapons pact}

[WASHINGTON] More than 140 chemists and biochemists belonging to the US National Academy of Sciences have added their voices to those urging the US Senate to move quickly to ratify the international Chemical Weapons Convention (CWC).

The treaty, which takes effect on 29 April, prohibits the development and use of chemical weapons and calls for signatories to destroy existing stockpiles.

Although more than 65 nations have already ratified the treaty - enough to bring the convention into force - neither the United States nor Russia is among them. And conservatives in Congress, led by Jesse Helms (Republican, North Carolina), who chairs the Senate Foreign Relations Committee, are threatening to hold up a vote to get their way on other foreign policy issues.

The petition by academy members, which was organized by Dudley Herschbach and Matthew Meselson of Harvard University, was due to be handed to the Senate majority leader, Trent Lott (Republican, Mississippi), this week. It asks him to work "as a matter of national urgency" to bring the convention to a vote before 29 April.

"If the Senate fails even to vote on the CWC ... the United States will have surrendered by default its essential leadership in combating the proliferation of chemical weapons," write the scientists.

Both the American Chemical Society and the American Physical Society have already written to the Senate in support of the CWC, and the Federation of American Scientists is organising a petition by Nobel prizewinners to urge ratification.

Only countries that have ratified the treaty by 29 April will be considered original signatories with full representation on the convention's governing council. Without a seat on the council, the United States would have no say in such matters as what threshold amounts of chemicals would be covered under the convention, according to Michael Walls of the Chemical Manufacturers Association (CMA), whose organization strongly supports ratification. The United States is also expected to contribute 25 per cent of the council's operating funds.

Although the treaty has wide bipartisan support, Lott will have to appease the conservative isolationist wing of his party, whose principal spokesman is Helms, to move the treaty out of the Foreign Relations Committee so it can come to a vote.

Two-thirds of the 100-member Senate need to approve ratification. The convention was on the verge of being approved last autumn before Bob Dole, the Republican presidential candidate, spoke out against it, forcing the Clinton administration to cancel what it regarded as a risky vote. Lott has appointed a group of ten senators, including himself and Helms, to work out a compromise with the White House.

Treaty supporters point out that the convention will take effect with or without the United States, and that the United States is already committed to destroying essentially all of its chemical weapons stockpile by 2005 , at a projected cost of $\$ 12.4$ billion. The cleanup is likely to be more expensive and to take longer than originally planned, according to a recent report by the congressional General Accounting Office (GAO).

Despite claims by opponents that the CWC would harm US chemical manufacturers, it is supported by virtually every affected industry and scientific group.

Manufacturers suspected of producing chemicals for weapons would be subject to inspection by international teams, but US industry groups are satisfied that confidential business information would be protected and that regular reporting requirements will not be onerous, according to Walls.

The consequences of non-ratification for US chemical manufacturers could be much worse, say supporters of the treaty. Beginning three years after the CWC takes effect, signatory nations would be prohibited from buying high-risk 'dual-use' chemicals (those with legitimate uses as well as being used for weapons) from non-signatories. These socalled 'Schedule 2' chemicals represent about $\$ 500-\$ 600$ million a year in business for US companies.

Tony Reichhardt 